\title{
Co-integration of Karachi Stock Exchange with Major South Asian Stock Exchanges
}

\author{
Salleh Nawaz Khan (Corresponding author) \\ Dept. of Mangement, The Islamia University, Bahawalpur \\ E-mial: sallehkhan@yahoo.com \\ Mohamad Saad Aslam \\ Dept. of Mangement, The Islamia University, Bahawalpur \\ E-mail: saad.aslam@yahoo.com
}

Accepted: May 02, 2014

DOI: 10.5296/ijafr.v4i1.5454 URL: http://dx.doi.org/10.5296/ ijafr.v4i1.5454

\begin{abstract}
International cross listing has amplified the interest of academics and investors to the subject of co- movement among the stock markets of the world. This study investigates the co integration of Pakistan stock exchange (KSE 100 index) with major stock exchanges of south Asia. The results reveal that there is no co integration of Pakistan's stock market (KSE100 index) with china and Japan stock markets. However there is co-integration of Pakistan's stock market (KSE 100 index) with the stock market of India, Indonesia, Malaysia and Singapore.
\end{abstract}

Keywords: Long rung relationship, Diversification, Co integration analysis, Stock market. 


\section{$\Lambda$ Macrothink}

\section{Introduction}

Globalization in capital market and reduction of restrictions on international cross listing have led to greater flows of capital between economies easier ownership and trading in securities from around the world. With the increase in market integration the current world financial markets have become more closely correlated and interdependence overtime. Understanding the information linkage and correlation between markets are important for financial decisions in relation to investment and risk management.

Fund managers are always looking for the securities that are not correlated for better opportunities to hedge risk. The study of co integration of stock markets is essential because it is a direct consequence of globalization and it has important implication for investors. Essentially the degree of stock market integration has major implication on potential benefits of international portfolio diversification and on financial stability of a country.

Stock markets integration suggests that separate stock markets move together and high correlation so there are fewer benefits from portfolio diversification across countries.

Despite there have been numerous studies focusing on market integration \& interdependence and very few of the existing studies have examined the international stock market linkage between Karachi stock exchange with other south Asian stock exchanges. The objective of this research is to understand the inter linkage between Karachi stock exchange $\mathrm{KSE}(100)$ with Bombay stock exchange BSE (30 index), Malaysian stock exchange (FTSE), and Singapore stock exchange (STI), Indonesia stock exchange (JKSE), Japan stock exchange

( Nikkei 225), and China stock exchange (his).

This paper is presented in four sections. Section 2 describes the previous literature and important results of previous findings; Section presents methodology i.e. how we carried out our research. Section present results and findings and Section 5 present conclusion and recommendation.

\section{Literature Review}

Most of the existing literature on the study of Inter linkages among markets have followed the approach that involves testing the interdependence directly using co integration approach and these studies have been done on concerning markets of developed and emerging countries. According to this approach, if stock prices indices of two or more countries are found to be co integrated then this implies that stock market of these countries are interdependent. Our study has also been designed on the basis of this approach and we have reviewed the literature pertaining to the same.

Grubel (1968) and Solink (1974) have documented the evidence that the correlation among national stock returns is low. This result implies that investors can gain benefit from international portfolio diversification. In addition Hung and Chenug (1995), studied the inter relationship of five major Asian emerging markets i.e. Hong Kong, Korea, 


\section{MInstitute Macrothink $_{\text {Int }}$}

International Journal of Accounting and Financial Reporting ISSN 2162-3082

Malaysia, Singapore and Taiwan they found weak long run relationship between these markets.

Researchers including Eun and Shim (1989) and Arshanpalli (1995) focus on the study how shocks in one markets are transmitted to other markets. Theses study finds that US market influence major markets of Asian regions while markets on Asian regions have little influence on US market.

Chung and NG (1991) investigate the relationship between US and Japan stock exchanges. Their results shows that US stock market have significant influence on the returns of Japanese stock market but Japan does not influence the returns of US market. Other studies including Kasa (1992) and Mash and Mash ( 2001) use co integration framework to examine the inter linkage between markets in Asian regions .

M. Need (2000) also investigate the short run and long run relationship between stock prices and exchange rate of four major south Asian countries? He employ vector error correction model and granger causality approach. Their finding shows that there is no short

run association ship between stock prices and exchange rates for Pakistan, India, Sri Lanka and Bangladesh also there is no long run relationship for Pakistan and India as well.

However the stock prices and exchange rates of Bangladesh and Sri Lanka have long run relationship. Nath. G and Verma (2003) emphases a study on co integration among south Asian markets. The markets of India, Singapore and Taiwan have been selected. They employed bi variant and multi variant co integration technique for finding interdependence among these markets. There results suggest that these markets have no long run relationship. So investor can diversified their risk by investing in these markets.

Wong Keung (2004) investigates the relationship between major developed countries and

Asian emerging markets. He also uses co integration approach for finding long run relationship between these markets. They finds that Singapore and Taiwan stock markets

have long run relationship with Japan while Hong Kong stock exchange has co integration

with US, and UK also there is no co integration between Malaysia, Thailand, Korea with developed markets of US, UK and Japan. S.verma and Golaka c Nath (2003) studied the co integration of south Asian markets i.e. India Singapore, and Taiwan. He found there is no co integration between these countries stock prices, so investor can diversify their risk.

Asjeet Lamba (2005) conduct an comprehensive analysis between south Asian equity markets he use Johannes test of co integration and VECM model .He found that Indian market is influenced by US, UK and Japan markets however Sri Lankan and Pakistani markets had not influenced by US, UK and Japan markets. These markets are isolated from major developed markets. Assideou komlavi (2008) investigate the co integration of major stock market indices during 2008 financial crisis. He use 


\section{MInstitute Macrothink $_{\text {Int }}$}

International Journal of Accounting and Financial Reporting ISSN 2162-3082

johensen test for co integration and suggest that Asian markets have long run association ship and Asian markets are influenced by European markets. Arshad Hassan (2008) studied the long run relationship between an emerging equity market and the equity market of the developed world. He found that Pakistan's stock exchange has no co integration with stock market of developed world.

Priyanka (2008) studied long run and short run integration in 15 countries with special focus on India .These countries and their respective stock exchanges are BSE 30 (India), France (CAC 40), Germany ( DAX 30), United Kingdon (FTSE 100), Hong Kong ( Hang Seng ), Indonesia ( JSX Composite) Malaysia( KLSE), Korea ( KOSPI), Pakistan ( KSE 100), United States ( Nasdaq), Japan ( Nikkei 225), China ( SSE Composite), Singapore (STI), Caneda ( S\&P) and Taiwan (TSEC). She finds that BSE 30 index has no long run association ship with any of market so investor can get benefit by diversifying their investment.

Bakri and Samsul (2009) investigate the relationship of Malaysia stock exchange with US, Japan and Singapore exchanges. They use ARDL approach for co integration and use weekly stock exchange data. Their results indicates that Malaysian market have long run association ship with US, Japan and Singapore market. So investors cannot diversify their risk by investing in these markets.

Ali Searat et al (2011) studied the co movement between emerging and developed stock markets. They use co integration analysis and found that there is no co movement of Pakistan's stock market with the market of UK, USA, Taiwan, Malaysia and Singapore however there is no movement of Pakistan's exchange with exchange of China Japan and Indonesia.

A.Iqbal and N. Khalid (2011) found no co integration among US, Pakistan and India stock markets by using Johansen co integration approach and granger causality statistics. The results indicate that New York stock exchange has stronger influence on Bombay and Karachi stock exchanges. Previous study have also documented on increase in correlation among European equity markets these decreases the benefit of diversification and also found no co integration between Asian stock exchanges, so investors can diversifies their risk.

A. Aisha and A. Fehmida (2012) studied the interrelationship of KSE 100 index with major south Asian exchanges. They employed Enger granger approach for co integration analysis. The results indicate KSE 100 index has co integrated with BSE (30 Index) however there is no co integration between KSE 100 index and KOSPI. Similarly there is no co integration between KSE 100 index and FTSE.

\section{Methodology}

\subsection{Data Description}

The study encompass the monthly stock prices from the period June 2007 to 
may 2013 consisted of 73 observations. The data is collected from stock exchanges websites and from yahoo finance. The selected sample consists of major indices of south Asian countries i.e. KSE 100 Index for Pakistan, BSE Sensex for India, NIKKEI 225 for Japan, FTSE 100 Index for Malaysia, Strait Time Index for Singapore, HangSeng Index for China, and Jakarta Composite Index for Indonesia.

\subsubsection{Procedure}

After getting the data of major indices of south Asian stock exchanges, the stock prices are converted into logarithm form to avoid the problem of hetroskedescity and make the calculation simple then the descriptive analysis will performed for finding the stochastic properties of data. The returns of the period June 2007 to may 2013 were calculated by

taking first difference.

Next step is to check the properties of data whether stock prices are stationary or not, if the stock prices will stationary then in that case we cannot use the technique of co integration then we will simply conduct regression analysis but if the stock prices are non stationary then

in that case we can't use regression technique because it will estimate the spurious regression in this case we will use co integration technique.

There are many test available for testing the stationary and non stationary properties of data but the most reliable test is augmented dickey fuller test ( ADF). The ADF test requires the lag selection, the most widely use is the Schwarz information criteria and becomes a standard

tool for selecting lag selection. For co integration technique it is a necessary condition that the variable should non stationary i.e. I(1) but after taking first difference it should become stationary i.e. I(0). So the ADF test, both with trend and without trend is applied on all stock prices at log level and at first difference form. Once the order of integration I (1) is established for each variable the next step is to evaluate the co integration properties. The technique used in the literature for co integration is; Engle Granger two step approach, Johansson Juselius and ARDL approach. But the Johansson and juselius test is preferred over other due to statistical reasons. The Johansson test for co integration required no. of lags, so before conducting Johansson test we have to find out the optimal no. of lag we will be after that we will be able to conduct Johansson test for co integration . So pair wise co integration test will be conducted.

\section{Results and Discussion}

This chapter is divided into three sections. Section 4.1 presents the descriptive statistics which are used to analyze the stochastic properties of the time series data. Section 4.2 presents the results of unit root test (ADF) which is employed to investigate the stationarity

of time series data. Section 4.3 presents the Johansen and Juselius co integration test. 


\section{Macrothink \\ International Journal of Accounting and Financial Reporting \\ ISSN 2162-3082 2014, Vol. 4, No. 1}

\subsection{Descriptive statistics.}

Descriptive statistic is presented in table 1. And table 2. At log level and log difference in term of mean, standard deviation, skewness, kurtosis, and j-b.

TABLE 1 . DESCRIPTIVE STATISTICS AT LOG LEVEL

\begin{tabular}{|c|c|c|c|c|c|c|c|}
\hline Market & Pakistan & India & China & Indonesia & Malaysia & Japan & Singapore \\
\hline Mean & 9.348905 & 9.703279 & 9.947032 & 7.975566 & 7.207382 & 9.267083 & 7.953233 \\
\hline Std.Dev & 0.285822 & 0.201241 & 0.171895 & 0.359876 & 0.18535 & 0.211121 & 0.188126 \\
\hline Skewness & -0.442485 & -1.717223 & -0.953409 & -0.645728 & -0.969782 & 0.92558 & -1.73688 \\
\hline kurtosis & 3.177349 & 5.381057 & 4.454369 & 2.774098 & 3.227978 & 2.908836 & 5.151887 \\
\hline $\mathrm{J}-\mathrm{b}$ & 2.443869 & 52.39456 & 17.25344 & 5.156667 & 11.44166 & 10.30531 & 43.60979 \\
\hline Prob. & 0.29466 & 0 & 0.000179 & 0.0759 & 0.003277 & 0.005784 & 0 \\
\hline
\end{tabular}

Description of the above table

The skewness of the data of all stocks indices are negative except Japan. The kurtosis value of Pakistan, India, china Malaysia and Singapore has greater than normal kurtosis so these indices are leptokurtic but Indonesia and Japan has platy kurtic because there values are smaller than normal kurtosis value. 


\section{Macrothink \\ International Journal of Accounting and Financial Reporting \\ ISSN 2162-3082 \\ 2014, Vol. 4, No. 1}

TABLE 2. DESCRIPTIVE STATISTIC AT LOG DIFFERENCE

\begin{tabular}{|l|ccccccc|}
\hline Market & Pakistan & India & China & Indonesia & Malaysia & Japan & Singapore \\
\hline Mean & 0.006483 & 0.004214 & 0.000395 & 0.012149 & 0.003763 & -0.003876 & -0.000973 \\
Std. Dev & 0.085222 & 0.081178 & 0.077082 & 0.076935 & 0.043031 & 0.069085 & 0.066584 \\
Skewness & -2.478513 & -0.330824 & -0.582536 & -1.830118 & -0.799206 & -0.853624 & -0.836573 \\
Kurtosis & 13.47436 & 4.787901 & 3.937238 & 10.92411 & 5.875443 & 4.847658 & 6.739957 \\
J-B & 397.258 & 10.75168 & 6.614263 & 225.3921 & 32.01832 & 18.72193 & 49.66065 \\
Prob. & 0 & 0.004627 & 0.036621 & 0 & 0 & 0.000086 & 0 \\
\hline
\end{tabular}

Description for the above table

Table 2. Represents the Descriptive statistic of stock returns i.e. stock prices at first difference for selected stock prices. The results reveals that Pakistan, India ,china, Indonesia , Malaysia, has positive returns but Japan and Singapore stock markets show negative returns. If we looks at the standard deviations of the stock markets we will find that Indonesia has higher standard deviation among others i.e. 0.359876 and Indonesia also shows greater returns among others i.e. 0.012149 (higher the risk higher the returns).

\section{Graphically Representation}

Here is the graphically representation of stock prices of all indices at level. All the graphs show at level show similar properties i.e. the data has intercept and also following some trend as well and have drift so we can say that all the indices under observation have non stationary data at level however we will further confirmed in later steps using unit root test. 

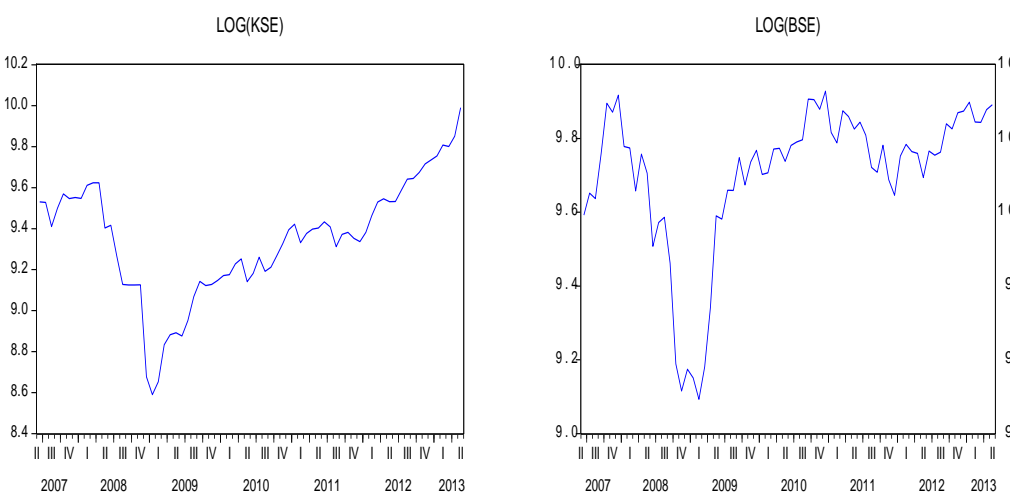
2014, Vol. 4, No. 1

LOG(JKSE)

LOG(KLSE)

LOG(HIS)
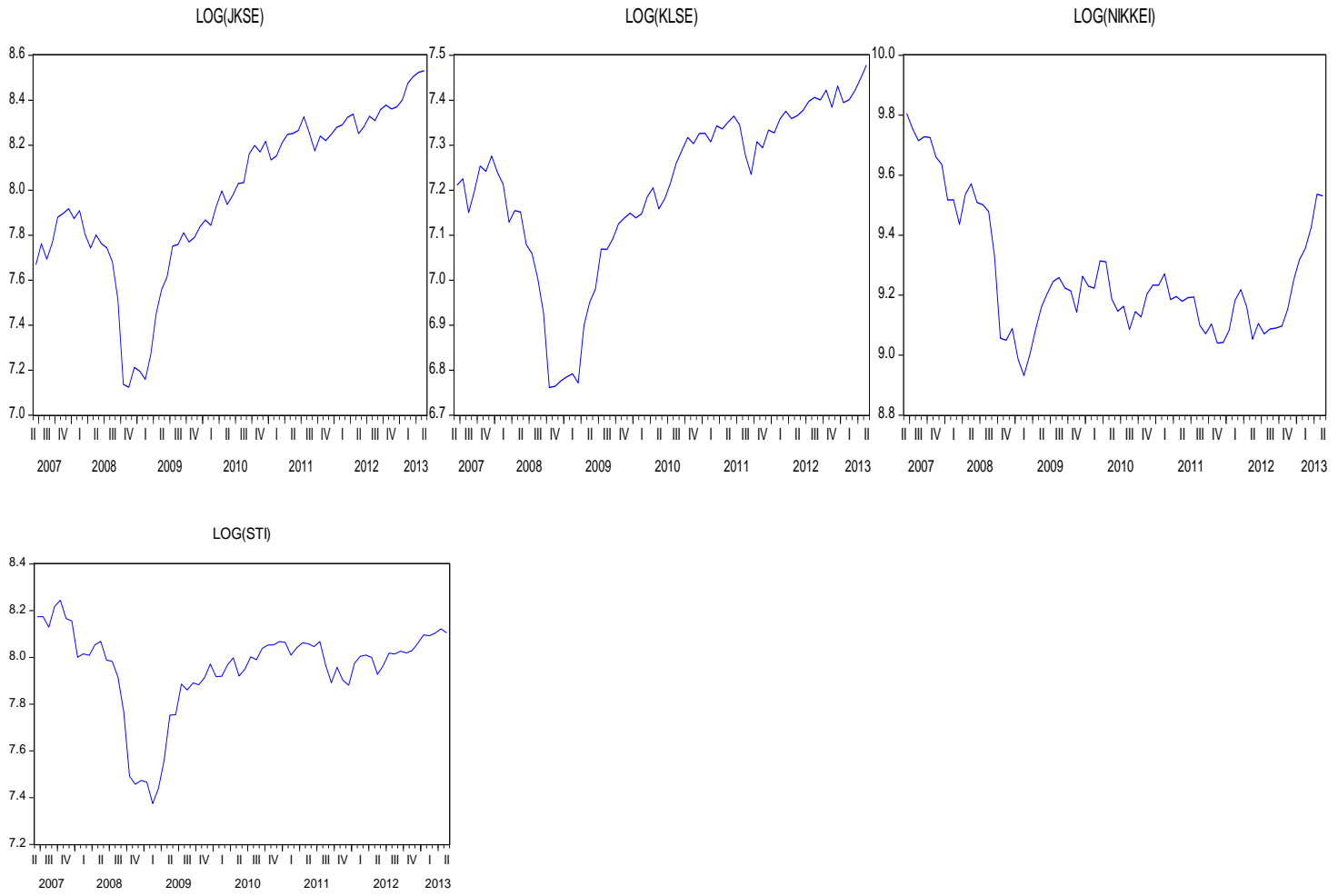

\section{GRAPHS AT LOG LEVEL}

\section{Graphically Representation at First Difference}

Here is the graphically representation of stock prices of all indices at first difference. All the graphs of stock indices have shown similar properties i.e. the data has moving around their mean with no trend so we can say that after taking first difference data becomes stationary. 

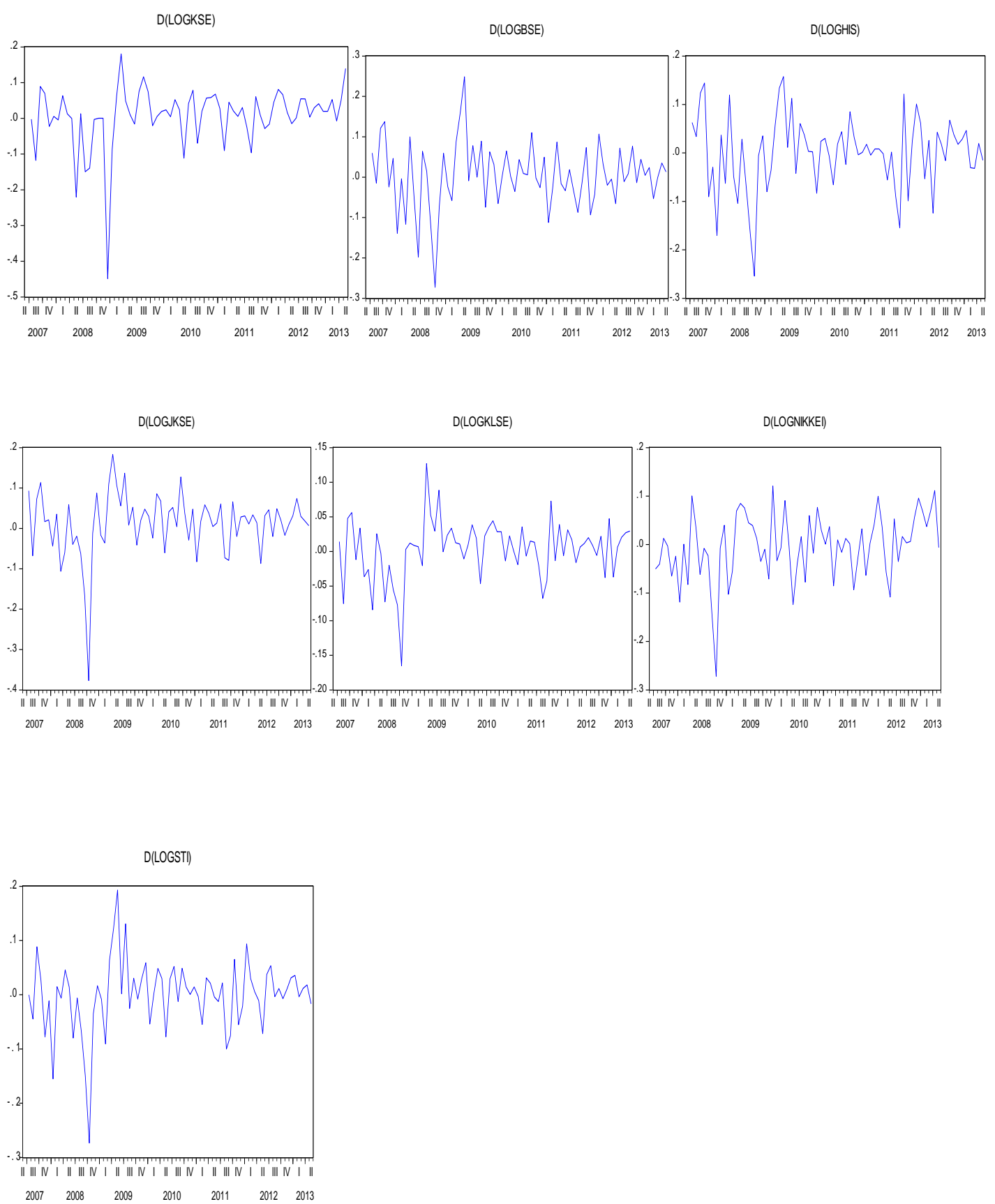

\section{GRAPHS AT FIRST DIFFERENCE}

\subsection{Unit Root Test.}

The results of the AUGMENTED DIKEY FULLER TEST are shown in table 3. If we look at the table we will found that all the stock prices are non stationary at level. As Augmented dickey fuller test statistics values are smaller than test critical values at bhot models at level i.e. with constant without trend and with constant and with trend. Hence ADF statistics is not significant at level. 
TABLE NO 3 AUMENTED DICKE FULLER TEST

Level

First difference

\begin{tabular}{|c|c|c|c|c|}
\hline Indices & intercept & intercept with trend & intercept & intercept with trend \\
\hline pakistan & -0.311740 & -1.268708 & $-6.687427^{* *}$ & $-7.016241 * *$ \\
\hline india & -1.619023 & -1.890396 & $-7.415722^{* *}$ & $-7.371919^{* *}$ \\
\hline china & -1.884074 & -1.862550 & $-7.280422^{* \bullet}$ & $-7.248179^{* 4}$ \\
\hline indonesia & -0.727243 & -2.267789 & $-6.327656^{\circ *}$ & $-6.346995^{* *}$ \\
\hline malaysia & -0.414634 & -1.977621 & $-6.885149^{* *}$ & $-7.012082^{* *}$ \\
\hline japan & -2.404492 & -1.547242 & $-6.698065^{* *}$ & $-7.111140 * 0 \mid$ \\
\hline singapore & -2.053682 & -2.293322 & $-6.468890^{* *}$ & $-6.527030^{\circ *}$ \\
\hline
\end{tabular}

Critical value at $5 \%$ with intercept is -2.902953 and critical value at $5 \%$ with intercept and trend is $-3.474363^{* *}$ indicates stationary of data at $5 \%$ critical.

However ADF statistics is significant after taking first difference. As ADF test statistics are greater than test critical values at both models i.e. With constant without trend and with constant with trend. Hence ADF statistics is significant at first difference. So now we can go to next step because unit root test confirms that data is non stationary at level but after taking first difference it becomes stationary.

\subsection{Cointegration test}

Results of co integration test is shown in table no. 4 pair wise cointegrtaion test were conducted among variables keeping Pakistan as dependent variable and India, China, Indonesia, Malaysia, Japan and Singapore as independent variable. First we confirm the results of cointegrtion with trace statistics and then doubled confirmed with max-eigen statistic.

Table 4 pairwise johansan cointegration test

\begin{tabular}{|c|c|c|c|c|}
\hline \multirow[b]{2}{*}{ indices } & \multicolumn{2}{|c|}{$\begin{array}{l}\text { unrestricted cointegration rank test } \\
\text { (trace) }\end{array}$} & \multicolumn{2}{|c|}{$\begin{array}{l}\text { unrestricted cointegration rank test } \\
\text { (max. eigenvalue) }\end{array}$} \\
\hline & Trace statistics & prob. & Max-eigen statistics & prob \\
\hline pakistan-india & $15.77808^{* *}$ & 0.0453 & $15.63830^{* *}$ & 0.0301 \\
\hline pakistan-china & 13.73802 & 0.0904 & 15.52664 & 0.0651 \\
\hline pakistan-indonesia & $19.99680^{* *}$ & 0.0098 & $15.06673^{* *}$ & 0.0373 \\
\hline pakistan-malaysia & $39.31955^{* *}$ & 0.0000 & $37.59409^{* *}$ & 0.0000 \\
\hline pakistan-japan & 9.516656 & 0.3197 & 0.922704 & 0.2600 \\
\hline pakistan-singapore & $16.96699^{* *}$ & 0.0298 & $16.72450^{* *}$ & 0.0200 \\
\hline
\end{tabular}

The results in table 4 reveals that there is co integration of Pakistani stock exchange with Indian, Malaysian, Indonesian, and Singapore stock exchange . As trace statistics is greater than critical value at $5 \%$ of significant level and even max -eigen statistics is also greater then critical value at $5 \%$ of significant 
level .So there is Long run Association between these markets. However there is no cointegration of Pakistan stock market with china and Japan stock markets. As trace statistics and max-eigen statistics has smaller values then their critical values at $5 \%$ of significant level. So these markets have no Long run Association.

\section{Conclusion and Recommendation}

This study empirically investigates the co integration of Pakistan's stock market with the stock market of India, china, Indonesia, Malaysia, Japan and Singapore . Monthly stock prices are taken for the period 2007-2013. From the descriptive statistic it is found that Indonesia stock market has highest returns among others and also highest standard deviation among others, as theory of Finance higher risk higher the return. It is also evident from the results that there is no co integration of Pakistan's stock market with the market of china and Japan, So this is the best situation because international investor can diversified their risk by investing in these markets. However there is co integration of Pakistan's stock market with the market of India, Indonesia, Malaysia and Singapore . So this condition is not good for international investors, risk cannot be diversified by investing in those markets because market returns of these countries are same .So investing in these markets yield same return either invest in Pakistan or in India, Singapore , Malaysia, and Indonesia.

It is also clear that the results of co integration vary due to selection of frequency of observations i.e. daily, weekly and monthly. This research use monthly data, so the potential area for further researches is to use high frequency data i.e. weekly and monthly. This research find the long run association between Karachi stock exchange with other major south Asian stock markets, So further researcher can find the short run association between these markets. Besides this other econometric techniques can be used like Engle granger and ARDL approach.

\section{References}

A. Aisha , A. Fehmida (2012). " co integration of karachi stock exchange with other Asian stock exchange,"

Ali Searat, Babar Zaheer ( 2011). "Co movement between emerging and developed stock market," journal of applied sciences ,12(4): 395-403.

Assidenou Komelavi (2008) . "co integration of major stock market indices," International journal of economics and finance, vol :3 no.2.

Arshanapalli B and J Doukas (1993). "International stock market linkage," journal of banking and finance, $17,193-208$.

Arshad Hassan , H.M.N.S M Shoaib Abdullah ( 2008). "Long run relationship between an 


\section{Macrothink}

International Journal of Accounting and Financial Reporting

ISSN 2162-3082

emerging equity market of the developed world an empirical analysis of Karachi stock exchange," International research journal of finance and economics, (16).

A.Iqbal,N Kaliq And S. Rafiq "Dynamic inter relationship among the stock markets of India , Pakistan and United States", International journal of human and social sciences , 6:1 2011.

Asjeet S Lamba . "AN ANALYSIS OF SHORT AND LONG RUN RELATIONSHIP BETWEEN SOUTH ASIAN AND DEVELOPED EQUITY MARKETS," international journal of business , 10 (4), 2005

Bukari Abdul Karim , M Shabri Abdul Majid ( 2009).” co integration of stock markets among Malaysia and its major trading partners," working paper series no. 0903.

Eun c, S. Shim (1989)." Interdependence of Asia emerging equity markets," journal of business finance and accounting, 22(20 pp 281-288.

Grubal.H(1968). "Internatioanl diversified portfolio" : welfare gains and capital flows , America economic review , 58, pp, 1299-1314.

Kasa , k (1992) . "common stock hastic trends in international stock market," jouranl of monetary economics, 29,95-124.

Masih, R,A,M.M.Masih ( 2001). "long run and short term dynamics casual transmission among international stock markets," journal of international money and finance , 20-563-587.

M. Naeem(2000). " stock prices and exchange rates' are they related? evidence of south asian countries," jel classification G15, G32.

Wong Keung(2004). "The relationship between stock markets of major developed countries and Asian emerging markets," journal of applied mathematics and sciences , 8(4), 201-218. 